\title{
DETERMINATION OF TEMPERATURE ON ICE CAPS BY SEISMIC METHODS
}

\author{
By F. Thyssen \\ (Institut für Reine und Angewandte Geophysik der Universität Münster, Münster, Westfalia, Germany)
}

\begin{abstract}
An empirical formula, derived by the author for the seismic velocities of $P$ waves in glaciers and ice caps, is used to determine the temperatures which can be deduced from the maximum and the mean vertical velocities. With the aid of several examples from previous publications, these temperatures are discussed and, as far as they are available, direct temperature measurements are compared with the derived temperatures.
\end{abstract}

RÉsumé. Détermination de la température des indlandsis par la méthode sismique. Une formule empirique établie par l'auteur pour les vitesses des ondes-P dans les glaciers et indlandsis est utilisée pour déterminer la température qui peut être déduite des vitesses maximum et verticales moyennes. A l'aide de plusieurs exemples de publications antérieures, ces températures sont discutées et, dans la mesure où elles sont connues, les mesures directes de températures sont comparées à celles déduites de la sismique.

Zusammenfassung. Temperaturbestimmung in Inlandeismassen mit seismischen Methoden. Eine vom Autor für die seismische Geschwindigkeit der P-Wellen in Gletschern und Inlandeismassen abgeleitete empirische Formel wird benutzt, um die Temperaturen $\mathrm{zu}$ bestimmen, die der Maximalgeschwindigkeit und der mittleren Vertikalgeschwindigkeit zugeordnet werden können. An Hand einiger Beispiele aus der Literatur werden die so erhaltenen Temperaturen diskutiert und, soweit vorhanden, direkte Temperaturmessungen den abgeleiteten Temperaturen gegenübergestellt.

According to the publications of Brockamp and Wölcken (1933) and Brockamp (1935), it is possible to correlate seismic velocities on ice caps with temperatures. A formula by Robin (1958) is sufficient to determine the seismic velocities in the Arctic and Antarctic regions with an error less than I per cent if the temperatures are known. It does not, however, allow the temperatures to be derived with reliability comparable to that of velocities, since these are subject to an error of only about o.I per cent.

Temperatures from the interior of ice caps can only be evaluated in so far as velocities can be measured from the surface or in bore holes. These are especially the maximum velocity of the refracted waves and the mean vertical velocity of the reflected waves. Both results can be obtained at the same time by exact seismic measurements.

The temperature values related to the maximum velocities and the mean vertical velocities would follow here. The maximum velocity indicates the temperature at the depth at which this velocity is measured and the mean vertical velocity indicates the mean temperature throughout the entire ice thickness. Usually the mean vertical velocity is corrected to evaluate the influence of firn. For this reason the mean ice velocity is determined. From this seismic velocity follows the mean temperature of the ice. The most important assumption is that, if seismic measurements are reliable, the velocities can be determined with an error of only about o.I per cent. Unfortunately, seismic work of this kind and with sufficient accuracy is rare even now in Arctic and Antarctic regions, because most of the measurements have been carried out with a view to determining only the ice thickness. It is, therefore, necessary to restrict discussion to the few available examples. The empirical formula used is given below (Thyssen, 1967):

$$
v=3.750-4.5 \times 10^{-3} T-0.5 \mathrm{e}^{-9 \times 10^{-5}} \mathrm{Hf}^{-6} \times \mathrm{10}^{-3} b(\mathrm{~km} / \mathrm{s})
$$

where $v=$ velocity $(\mathrm{km} / \mathrm{s}), T=$ temperature $\left({ }^{\circ} \mathrm{C}\right), H=$ ice thickness $(\mathrm{m}), f=$ frequency of seismic wave $(\mathrm{Hz}), b=$ brine concentration $(\%)$.

The formula has been confirmed for $o<T \leqslant-28^{\circ} \mathrm{C}$ and $H f>2000 \mathrm{~m} / \mathrm{s}$, and for $b$ at a first approximation with $b<0.5$ per cent. It was derived for velocities measured at very great distances, thereby eliminating the dependence on the firn density. For small ice thicknesses and at distances which are much greater than the ice thicknesses, seismic velocities have been measured which can range between the velocity of the wave in a half space and the velocity of the plate wave (for example, in ice shelves), the value being dependent on the parameter $H f$. This part of the formula is not sufficiently reliable to guarantee the necessary precision for a temperature determination. Velocity determinations which neglect this part of the formula should not be used for temperature determination without qualification. 
The same applies to the ice which contains water in temperate glaciers. The seismic velocities of this ice depend on the water content and are lower than $3750 \mathrm{~m} / \mathrm{s}$, i.e. the seismic P-wave velocity in dry ice at $0^{\circ} \mathrm{C}$.

In the following only those velocities are used for temperature determination when the thickness and the water content can be neglected. The temperature determination is based on

$$
v=3.750-4.5 \times 10^{-3} T(\mathrm{~km} / \mathrm{s})
$$

and thus on the temperature determination by the maximum velocity of very thick ice sheets. To extend the range for which it was derived, this relation can be employed in all cases for which the density values are equal to those measured at depths where the maximum velocities first occur. For the determination of temperatures only, ice of a density greater than $0.9 \mathrm{~g} / \mathrm{cm}^{3}$ is used. A more exact value for density, its dependence on temperature and the other conditions for densification need not be stated here.

It is to be expected that pressure and the diminuation of the ice porosity result in some increase in the seismic velocity, but these conditions are not considered in the above formula. From existing knowledge, these factors are small. Because of these factors, the mean vertical temperature derived from this formula is systematically slightly too low. (Estimated value at $2000 \mathrm{~m}$ of ice is about $-\mathrm{r}^{\circ} \mathrm{C}$.)

The influence of possible anisotropy of the ice cannot be considered for the present, since insufficient data are available. Furthermore, it is not clear whether this effect would in general lead to temperatures which are too high or too low. However, it may be assumed that this factor is very often over-estimated and in the following it will be neglected.

The best comparison between velocities, densities, measured temperatures and temperatures derived by the above formula can be obtained by measurements in bore holes. For the results of seismic borehole measurements where there is sufficient depth, the influence of thickness discussed above can be neglected.

Thiel and Ostenso ( $196 \mathrm{r}$ ) have given depths, density values and seismic P-wave velocities for a borehole $\log$ at "Little America V". These data are supplemented by temperature values from a diagram in the same publication. The temperatures derived by the formula have been compared with the measured ones, and only data for an ice-core density greater than $0.9 \mathrm{~g} / \mathrm{cm}^{3}$ have been taken. For comparison, this is further supplemented by the velocity and temperature at $100 \mathrm{~m}$, at which depth the ice-core density is only $0.899 \mathrm{~g} / \mathrm{cm}^{3}$.

$\begin{array}{ccccc}\text { Depth* } & \text { Density* } & \begin{array}{c}\text { P-wave } \\ \text { velocity* }\end{array} & \begin{array}{c}\text { Temperature } \\ \text { derived by } \\ \text { the formula }\end{array} & \begin{array}{c}\text { Measured } \\ \text { temperatures* }\end{array} \\ \mathrm{m} & \mathrm{g} / \mathrm{cm}^{3} & \mathrm{~m} / \mathrm{s} & { }^{\circ} \mathrm{C} & { }^{\circ} \mathrm{C} \\ 100 & 0.899 & 3835 & -19 & -20.5 \\ 150 & 0.904 & 3828 & -17 & -17 \\ 200 & 0.904 & 3811 & -13.5 & -13.5 \\ 240 & 0.904 & 3795 & -10 & -7\end{array}$

* According to Thiel and Ostenso (196r).

The agreement between the calculated and the measured temperatures indicates that the formula can be used for temperature estimation on inland ice sheets where no bore holes are available.

Behrendt (1963) made extensive seismic measurements during the Antarctic Peninsula oversnow traverse. The results from "Eights" station will be specifically discussed here, because at this place the mean vertical velocity in the ice was determined. The maximum velocity at a depth of about $200 \mathrm{~m}$ is $3870 \pm 5 \mathrm{~m} / \mathrm{s}$ and the mean vertical velocity in the ice after correction of the upper $200 \mathrm{~m}$ is $3814 \pm 15$ $\mathrm{m} / \mathrm{s}$. A temperature of $-26.5 \pm \mathrm{I}^{\circ} \mathrm{C}$ can be derived from the maximum velocity and a temperature of $-\mathrm{I} 4 \pm 3^{\circ} \mathrm{C}$ from the mean vertical velocity in the ice. The temperature at "Eights" station is $-24^{\circ} \mathrm{C}$ at a depth of ro m (Bentley, [ [ $\left.{ }^{c}{ }_{1964}\right]$, fig. 31 ). According to this, a value of $-26.5 \pm 1^{\circ} \mathrm{C}$ at a depth of $200 \mathrm{~m}$ is quite likely, whereas the mean vertical temperature derived from the above formula differs from the temperature values deduced by Behrendt (1963). Within the limits of the stated procedure, the mean vertical temperature is equal to the temperature which can be derived from a linearly increasing temperature between a depth of $200 \mathrm{~m}$ and $-26.5^{\circ} \mathrm{C}$ down to the ice/rock interface at $0^{\circ} \mathrm{C}$. Apart from this simple solution, there are yet other more complicated temperature distributions which would result in the same mean temperature. Certainly in the possible distribution of temperatures the existence of 
values near the melting point can be expected near the ice/rock boundary. But the problem is complicated by reflexions from the interior of the ice. Therefore, in this case it is not possible to reach an undoubted conclusion that the mean vertical velocity is influenced only by temperature. Other factors, for instance the presence of a moraine, have already been discussed by Behrendt (1963). If the above temperature data are reliable, such a moraine should be at least partially at the melting point. The ice thickness at "Eights" station is quoted by Behrendt as 2 I $10 \mathrm{~m}$ with a bedrock elevation at $-\mathrm{I} 670 \mathrm{~m}$.

Bentley and others (1957) have given for the refracted wave at "Site 2" on the Greenland ice sheet a maximum velocity of $3.865 \pm 0.01 \mathrm{~km} / \mathrm{s}$ at a depth of $350 \mathrm{~m}$, and a mean vertical velocity in the ice (after correction of the effect of the firn) of $3.845 \pm 0.015 \mathrm{~km} / \mathrm{s}$. In addition to others, this maximum velocity was used to derive the above-mentioned empirical formula, and temperatures of $-25.5 \pm 2{ }^{\circ} \mathrm{C}$ and $-2 \mathrm{I} \pm 3^{\circ} \mathrm{C}$ can be derived from these velocities. A temperature of $-25.3^{\circ} \mathrm{C}$ was measured in a bore hole at a depth of $300 \mathrm{~m}$.

For comparison with the results from "Site 2" (lat. $76^{\circ} 59^{\prime}$ N., long. $56^{\circ}$ o $5^{\prime}$ W.; i $820 \mathrm{~m}$ of ice and firn), the recently published data (Hansen and Langway, 1966) for the bore hole at "Camp Century" (lat. $77^{\circ}$ 10 $^{\prime} \mathrm{N}$., long. $6 \mathrm{r}^{\circ} \mathrm{o} 8^{\prime}$ W.; $\mathrm{I} 387.4 \mathrm{~m}$ of ice and firn) is used. At the ice/rock boundary the "Camp Century" bore hole has a temperature of $-13{ }^{\circ} \mathrm{C}$. The lowest temperature is $-24.6^{\circ} \mathrm{C}$ at a depth of $154 \mathrm{~m}$, and the temperature gradient is not linear throughout the entire depth. The mean temperature can therefore be estimated as being somewhat lower than $-18.8^{\circ} \mathrm{C}$, which is the mean value for a linear increase of temperature. The publication of further data for the "Camp Century" bore hole will be of great interest.

If the temperature at the lower boundary of the ice at "Site 2 " is assumed to be -13 " $\mathrm{C}$ with a temperature distribution similar to that at "Camp Century", the mean temperature at "Site 2 " must be somewhat lower than $-19.2^{\circ} \mathrm{C}$, and it lies close to the derived temperature of $-2 \mathrm{I} \pm 3^{\circ} \mathrm{C}$.

Unfortunately, not all of the examples given here allow a direct comparison of seismically derived temperatures with temperature measurements in situ, since the number of bore holes is as yet too small. The boring technique developed at "Camp Century" will make it possible in the near future to carry out further direct measurements in order to prove the above formula and to discuss the effects of pressure and anisotropy which have been neglected in it.

MS. received 3 March 1967

\section{REFERENCES}

Behrendt, J. C. 1963. Seismic measurements on the ice sheet of the Antarctic Peninsula. Fournal of Geophysical Research, Vol. 68, No. 21, p. 5973-90.

Bentley, C. R. [ ${ }^{{ }^{1}}{ }_{1964 .]}$ The structure of Antarctica and its ice cover. (In Odishaw, H., ed. Research in geophysics. Vol. 2. Solid earth and interface phenomena. Cambridge, Mass., M.I.T. Press, p. 335-89.)

Bentley, C. R., and others. 1957. Seismic measurements on the Greenland ice cap, by C. R. Bentley, P. W. Pomeroy, H. J. Dorman. Annales de Géophysique, Tom. 1 3, Fasc. 4, p. $253-85$.

Brockamp, B. 1935. Uberlegungen zur Temperaturverteilung im Inlandeis auf Grund seismischer Ergebnisse. (In Brockamp, B., and others. Glaziologie. Leipzig, F. A. Brockhaus, p. $4^{1-5}$. (Wissenschaftliche Ergebnisse der deutschen Grönland-Expedition Alfred Wegener I929 und I930/193I, Bd. 3.))

Brockamp, B., and Wölcken, K. I933. Die seismischen Ergebnisse der Hauptexpedition bis "km I20". (In Brockamp, B., and others. Seismik. Leipzig, F. A. Brockhaus, p. 1-91. (Wissenschaftliche Ergebnisse der deutschen Grönland-Expedition Alfred Wegener 1929 und $1930 / 1931$, Bd. 2.))

Hansen, B. L., and Langway, C. C., jr. 1966. Deep core drilling in ice and core analysis at Camp Century, Greenland, 1961-1966. Antarctic fournal of the United States, Vol. 1, No. 5, p. 207-08.

Robin, G. de Q. 1958. Glaciology. III. Seismic shootings and related investigations. Norwegian-BritishSwedish Antarctic Expedition, 1949-52. Scientific Results (Oslo, Norsk Polarinstitutt), Vol. 5.

Thiel, E., and Ostenso, N. A. 1961. Antarctic ice shelves. Geophysics, Vol. 26, No. 6, p. 706-15.

Thyssen, F. 1967. Die Temperaturabhängigkeit der P-Wellengeschwindigkeit in Gletschern und Inlandeisen. Zeitschrift für Geophysik, Jahrg. 33, Ht. 2, p. 65-79. 